\title{
Understanding the Link Between Self-Esteem and Work-Family Enrichment
}

\author{
Herdiana $^{1, *}$, Elvita Bellani ${ }^{2}$, Sri Wahyuni ${ }^{3}$ \\ ${ }^{I}$ Psychology Department, Medical Faculty, Hasanuddin University, Indonesia \\ 2 Psychology Department, Medical Faculty, Hasanuddin University, Indonesia \\ ${ }^{3}$ Psychology Department, Medical Faculty, Hasanuddin University, Indonesia \\ *Corresponding author.Email: herdiana.hdn@gmail.com
}

\begin{abstract}
Work-family enrichment has been linked with a myriad of positive outcomes. Understanding factors related to work-family enrichment is important to enhance employees' productivity and quality of life, including health workers. This present study investigates the relationship between self-esteem and work-family enrichment in health workers. There were 187 employees of Gowa Regional Public Hospital participated in this study. Data were collected using Work-Family Enrichment Scale and Rosenberg's Self-Esteem Scale (RSES). Pearson correlations revealed that self-esteem is positively correlated to work-to-family and family-to-work enrichment. This result demonstrated that employees with high levels of self-esteem are more likely to experience the positive spillover of work into family and family into work.
\end{abstract}

Keywords: Work-family enrichment, self-esteem, employee.

\section{INTRODUCTION}

Today, organizations compete, innovate rapidly, and experience continuous changes [1][2]. In dealing with this situation, organizations need employees that meet their own desired level of job performance. However, some employees could not achieve the high performance required, resulting in low performance. The undesired situation was related to the fact that an employee has another role outside of their working life; one of the most crucial is a role as a family member.

Netemeyer [3] stated that the demand for responsibility for roles in the family could make it difficult for employees to engage in their roles at work if the two conflicted. Individuals' poor performance in multiple roles is also in line with Edward and Rothbard [4], who stated that each individual has limited energy to share to perform various roles. In work-family interface literature, this is known as work-family conflict, defined as a form of inter-role conflict in which the pressure from work and family negatively influences the individual [5].

In contrast to various views related to involvement in several roles that consume energy and generate conflict, Marks [6] argued that participation in some roles generates valuable energy and can be used in different roles. In addition, Ruderman, et al. [7] and Crouter [8] also conducted research showing that involvement in various roles produces resources that can be used to improve oneself in other roles.

The positive interaction that is formed between work and family is termed work-family enrichment. Greenhaus and Powell [9] defined work-family enrichment as: "the extent to which experience in one role improves the quality of life, in this case, performance or affect of other roles".

In the work-family enrichment theory model, resources are defined as an asset that individuals can use when faced with certain situations [9]. The collection of resources is an essential factor to encourage the enrichment process [10][11][12]. One of the resources included in the work-family enrichment theory model is self-esteem. According to Greenhaus and Powell [9], self-esteem can improve individual performance because self-esteem stimulates motivation, effort, persistence, and determination.

Grimm-Thomas and Perry Jenkins [13] also found that self-esteem mediates the relationship between 
job complexity and positive parenting behavior, which indicates that self-esteem will help the process of an experience in one role improve performance in other roles. Another study conducted by Rashid, et al. [14] on 689 married nurses in Malaysia showed that self-esteem positively correlates with work-family enrichment. Korman [15] also found that the higher the individual's self-esteem, the higher the tendency to see themselves successful in managing work-life balance and their family. Accordingly, this study aims to investigate the relationship between selfesteem and work-family enrichment in health workers.

\section{LITERATURE REVIEW}

\subsection{Work-Family Enrichment}

Greenhaus \& Powell [9] defined work-family enrichment as the extent to which experience in one role can improve the quality of life in other roles. The intended quality of life consists of high performance and positive affect (Greenhaus and Powell explained that affect is a positive mood and positive emotion gained from experiences in one role). Work-family enrichment is bidirectional; work-to-family enrichment (WFE) and family-to-work enrichment (FWE). WFE occurs when experiences at work can increase performance or affect the family role, and FWE occurs when experiences in the family can improve performance or affect individual roles in the workplace [9].

In the work-family enrichment theoretical model, a resource is a vital element in the enrichment process. The process of transferring resources obtained from a role which can then be applied and helps improve the quality of individuals in other roles occurs through two paths named the instrumental path and positive affect. The instrumental path is when resources obtained in one role are transferred and applied to a second role, resulting in increased performance in the said role. At the same time, positive affect is a path when resources obtained from a role produce positive affect, which improves performance in that role [9].

\subsection{Self-Esteem}

Santrock [16] revealed that self-esteem is a global evaluation of self. Meanwhile, according to Rosenberg [17], in simple terms, self-esteem is defined as an individual's subjective evaluation of themselves, both positive and negative, as a whole. Rosenberg added that individuals may have high selfesteem and consider themselves superior to others but feel they have not reached their specific standards. On the other hand, individual may think of themselves as ordinary people yet is entirely satisfied with themselves.

Individuals with high self-esteem are expressed with a feeling of "good enough" where the individual feels that they are worthy; individuals value themselves as they are. However, individuals do not feel very satisfied or proud of themselves or hope that others will feel very satisfied or proud of themselves. Individuals with high self-esteem do not merely accept themselves as they are, but individuals want to grow, improve, and overcome their flaws [17].

\subsection{Self-Esteem and Work-Family Enrichment}

Greenhaus and Powell [9] noticed that self-esteem (the individual's subjective assessment of themselves as a whole [17]) facilitates improving the quality of life of individuals through affective path because self-esteem stimulates motivation, effort, persistence, and individual determination on goals.

Research on self-esteem consistently showed that individuals with high self-esteem tend to have high positive affect [18]. The research conducted by Wood, et al. [19] shows that self-esteem is a predictor of positive affect regulation, which means that the level of self-esteem can predict how individuals maintain their positive affect. In other words, the higher self-esteem an individual possesses, the higher the possibility of having or maintaining the said positive effect. Consequently, self-esteem can directly produce positive affect in a role because it provokes positive moods and positive emotions in that role [20]

Self-esteem can also help resources-transferring from multiple roles through the occurrence of high performance in one role. The feeling of "good enough" that presents in individuals with high selfesteem will make individuals accept their strengths and weaknesses and want themselves to grow and develop [17]. The individual's desire to grow and develop will become the driving force to do their best in their roles, resulting in high performance.

Based on the explanation following the theoretical model of work-family enrichment by Greenhaus and Powell [9] and previous studies, this study aims to understand the relationship between self-esteem and work-family enrichment. 


\section{METHOD}

\subsection{Participants}

Participants were 187 employees of Gowa Regional Public Hospital: all medical staff and other workers who supported health services at the hospital.

\subsection{Procedures}

We provided participants with informed consent along with the research questionnaires. A total of 300 questionnaires were distributed to employees, and there were only 187 questionnaires $(62.3 \%)$ that met the criteria for this study.

\subsection{Measures}

\subsubsection{Work-Family Enrichment}

Work-family enrichment was measured using the Work-Family Enrichment scale adapted by Kariimah [21] based on the Work-Family Enrichment scale by Carlson, et al. [22]. This scale consists of 18 items divided into two subscales according to the direction of work-family enrichment: work-to-family enrichment (WFE) and family-to-work enrichment (FWE). The RMSEA value of this scale is .79, and each item has a C.R.> 1.96 value, which means the scale is accepted as a fit model. The reliability of the scale is at a value of .973 .

\subsubsection{Self-Esteem}

Self-esteem was measured using the Rosenberg Self-Esteem Scale (RSES) by Rosenberg [17], adapted into Indonesian. This scale consists of 10 unidimensional items. Before being distributed, the readability test was conducted on ten respondents with the same characteristics as the research participants. The RMSEA value of this scale is .78, and each item has a C.R.> 1.96 value, which means the scale is accepted as a fit model. The reliability of the scale is at a value of .779 .

\section{RESULT}

The following are tables describing the results of descriptive statistics (table 1 and 2) and correlation between the two variables (table 3 and 4 ).
Table 1. Descriptive statistics of WFE

\begin{tabular}{lll} 
& N & Mean \\
\hline Work-to- & 187 & 36.64 \\
Family & & \\
Enrichment & & \\
\hline Family-to- & 187 & 36.95 \\
Work & & \\
Enrichment & & \\
\hline
\end{tabular}

Table 2. Descriptive statistics of self-esteem

\begin{tabular}{lll} 
& N & Mean \\
\hline Self-Esteem & 187 & 31.45 \\
\hline
\end{tabular}

Table 3. Correlation analysis of self-esteem and work-to-family enrichment

\begin{tabular}{lcc}
\hline & $\begin{array}{c}\text { Bootstrap } \\
\text { Correlation }\end{array}$ & $\begin{array}{c}\text { Pearson } \\
\text { Correlation }\end{array}$ \\
\hline Coefficient & .440 & .440 \\
\hline Significance & .000 & .000 \\
\hline Bias & .002 & \\
\hline $95 \%$ & .303 & \\
Confidence & & \\
Interval & & \\
Lower & & \\
\hline 95\% & .563 & \\
Confidence & & \\
Interval & & \\
Upper & & \\
\hline
\end{tabular}

Table 4. Correlation analysis of self-esteem and family-to-work enrichment

\begin{tabular}{lcc}
\hline & $\begin{array}{c}\text { Bootstrap } \\
\text { Correlation }\end{array}$ & $\begin{array}{c}\text { Pearson } \\
\text { Correlation }\end{array}$ \\
\hline Coefficient & .332 & .332 \\
\hline Significance & .000 & .000 \\
\hline Bias & .000 & \\
\hline $95 \%$ & .166 & \\
Confidence & & \\
Interval & & \\
Lower & & \\
\hline 95\% & .491 & \\
Confidence & & \\
Interval & & \\
Upper & & \\
\hline
\end{tabular}

Based on the tables, the correlation coefficient of self-esteem and work-to-family enrichment is .440** (positive and significant), and the correlation coefficient of self-esteem and family-to-work enrichment is $.332 * *$ (positive and significant). The 
significance value of each correlation coefficient is .000 . It is at the $95 \%$ significance level, which means the relationship between self-esteem and both directions of work-family enrichment is in a positive direction. In addition, the bias values of the bootstrap results are .002 and .000 , which indicate that the comparison between the statistical mean value of the entire bootstrap samples (1,000 samples) and the statistical mean value of the original samples (187 samples) are only .002 and .000. For the confidence interval results, if all 1,000 bootstrapping samples were sorted, the lowest correlation coefficients would be .303 (WFE) and .166 (FWE). Meanwhile, the upper correlation coefficients would be .563 (WFE) and .491 (FWE), with a 95\% confidence level. The results also showed that the correlation coefficients presented by the bootstrap method and the Pearson method are in the range of the correlation coefficient value from the $95 \%$ confidence interval.

\section{DISCUSSION}

This study was conducted to investigate the relationship between self-esteem and work-family enrichment. The results of data analysis found that the relationship between self-esteem and work-family enrichment was at a moderate level; work-to-family enrichment with a correlation coefficient of .440 (positive and significant) and family-to-work enrichment with a correlation coefficient of .332 (positive and significant).

In this study, several participants explained how self-esteem could help them in both roles. The participants in this study declared that some positive self-images motivated and made them excited to carry out their duties in roles at home and work. That would lead to the participants' efforts to maintain their positive images by working harder and being more actively involved in their families. In other words, as a part of psychological and physical resources, self-esteem can directly motivate individuals, which leads to high performance in individual roles.

Greenhaus \& Powell [9] emphasized that many of the resources gathered from experiences in a role are interdependent. A resource is defined as an asset that an individual can use when needed to solve a particular problem or situation. Individuals with high self-esteem can improve their performance in other roles because self-esteem stimulates motivation, goalsetting, effort, and persistence [14]. In addition, individuals who think that they are capable will do or complete tasks and responsibilities in a role with confidence and have a consistently positive attitude towards various situations [22]. Some of these descriptions showed that self-esteem as part of psychological and physical resources can stimulate the process of obtaining other resources for individuals.

Longitudinal research conducted by Kuster, et al. [23] also found that self-esteem can prospectively predict positive changes in almost all individual work conditions and outcomes. Korman [15] supports that that study, who suggested that self-esteem is positively related to individual job performance. This present study also revealed that some participants considered having a job and working gave rise to a feeling that they had contributed to their families, resulting in a sense of achievement. Positive emotions possessed by the participants indicated that in this study, with the presence of self-esteem or feelings of worth, work-family enrichment can occur through the affective path. Several studies on selfesteem also consistently showed that individuals with high self-esteem tend to have increased positive affect [18]. Therefore, as revealed in this study, selfesteem also helps work-family enrichment through the affective path.

To summarise, this study found that self-esteem helps the enrichment process, in line with the WorkFamily Enrichment theory model by Greenhaus \& Powell [9]. In this study, self-esteem has helped the enrichment process through instrumental and affective paths. The instrumental track occurs when self-esteem directly results in a good performance in one's role. Meanwhile, the affective path occurs when self-esteem produces positive emotions in a role, leading to achieving two components of quality of life: high performance and positive affect. In addition, the results are also in line with the idea of Greenhaus \& Powell [9], which argued that selfesteem could stimulate the acquisition of other resources in individuals, which will then assist the enrichment process.

\section{CONCLUSION}

The intense competition experienced by the organization makes the organizations need to pay more attention to the work-family enrichment conditions of its employees. In addition to providing positive outcomes for the organization, work-family enrichment also positively impacts the employee's role in their family. This study reveals and supports the Work-Family Enrichment theory model that selfesteem, as a part of psychological and physical resources, is a variable that promotes the process of 
work-family enrichment through the two enrichment paths proposed by Greenhaus \& Powell [9].

\section{REFERENCES}

[1] M.A. Griffin, A. Neal, S.K. Parker, A new model of work role performance: Positive behavior in uncertain and interdependent contexts, in Academy of Management Journal, 2007, pp. 327-347.

[2] D.R. Ilgen, E.D. Pulakos, The changing nature of performance: Implications for staffing, motivations, and development, Jossey-Bass, San Fransisco, 1999.

[3] G.R. Netemeyer, J.S. Boles, R. McMurrian, Development and Validation of Work-Family Conflict and Family-Work Conflict Scales, in Journal of Applied Psychology 1996, vol. 81, 1996, pp. 400-410.

[4] J.R. Edwards, N.P. Rothbard, Mechanisms linking work and family: Clarifying the relationship between work and family constructs, in Academy of Management Review, vol. 25, 2000, pp. 178-199.

[5] J.H. Greenhaus, N.J. Beutell, Sources of conflict between work and family roles, in Academy of Management Review, vol. 10, 1985, pp. 76-88.

[6] S.R. Marks, Multiple roles and role strain: Some notes on human energy, time and commitment, in American Sociological Review, vol. 42, 1997, pp. 921-936.

[7] M.N. Ruderman, P.J. Ohlott, K. Panzer, S.N. King, Benefits of multiple roles for managerial women, in Academy of Management Journal, vol. 45, 2002, pp. 369-386.

[8] A. Crouter, Participate work as an influence on human development, in Journal of Applied Developmental Psychology, vol. 5, 1984, pp. 71-90.

[9] J.H. Greenhaus, G.N. Powell, When work and family are allies: A theory of work-family enrichment, in Academy of Management Review, vol. 31, 2006, pp. 72-92.

[10] S.D. Friedman, J.H. Greenhaus, Work and family_allies or enemies? What happens when business professionals confront life choices, Oxford University Press, New York, 2000.
[11] J.H. Greenhaus, S. Parasuraman, Research on work, family, and gender: Current status and future directions, in: G.N. Powell (Eds.), Handbook of gender and work, Sage, US, 1999, pp. 391-412.

[12] J.G. Grzywacz, Toward a theory of work-family enrichment, in Paper presentation $34^{\text {th }}$ Annual theory construction and research methodology workshop, Houston, 2002.

[13] K. Grimm-Thomas, M. Perry-Jenkins, All in a day's work: Job experiences, self-esteem, and fathering in working class families, in Family Relations, vol. 43, 1994, pp. 174-181.

[14] W.E.W. Rashid, M.S. Nordin, A. Omar, I. Ismail, Measuring Self-Esteem, Work-Family Enrichment and Life Satisfaction: An Empirical Validation, in 2011 International Conference on Sociality and Economics Development, vol. 10, 2011, pp. 576-581.

[15] A.K. Korman, Hypothesis of work behavior revisited an extension, in Academy of Management Review, vol. 1, 1976, pp. 50-63.

[16] J.W. Santrock, Adolescence: An Introduction $11^{\text {th }}$ Edition, McGraw Hill, USA, 2007.

[17] M. Rosenberg, Society and the adolescent selfimage, Princeton University Press, NJ, 1965.

[18] T. Krieger, H. Hermann, J. Zimmermann, M.G. Holtforth, Associations of self-compassion and global self-esteem with positive and negative affect and stress reactivity in daily life: Findings from a smart phone study, in Personality and Individual Differences, vol. 87, 2015, pp. 288292.

[19] J.V. Wood, S.A. Heimpel, J.L. Michela, Savoring Versus Dampening: Self-Esteem Differences in Regulating Positive Affect, in Journal of Personality and Social Psychology, vol. 85, 2003, pp. 566-580.

[20] A.M. Isen, R.A. Baron, Positive affects as a factor in organizational behavior, in Research in Organizational Behavior, vol. 13, 1991.

[21] N. Kariimah, The Relationship Between SelfEfficacy and Work-Family Enrichment in Married Employees Working in X Company in Makassar City, Undergraduate Thesis, 2018.

[22] D.S. Carlson, K.M. Kacmar, J.H. Wayne, J.G. Grzywacz, Measuring the positive side of the work family interface: Development and 
validation of a work-family enrichment scale, in Journal of Vocational Behavior, vol. 68, 2006, pp. 131-164.

[23] F. Kuster, U. Orth, L.L. Meier, High SelfEsteem Prospectively Predicts Better Work Conditions and Outcomes, in Social Psychological and Personality Science, vol. 4, 2013, pp. 668-675. 